\title{
Hijrah Movement in Indonesia: Shifting Concept and Implementation in Religiosity
}

\author{
Nurul Annisa Hamudy, ${ }^{1}$ Moh. Ilham A. Hamudy ${ }^{2 *}$ \\ ${ }^{1}$ Sekolah Tinggi Filsafat Driyarkara, Jakarta - Indonesia, ${ }^{2}$ Badan Penelitian dan \\ Pengembangan Kementerian Dalam Negeri Republik Indonesia, Jakarta - Indonesia
}

\begin{abstract}
Hijrah is considered as a change in attitude and religious experience, from looseness to strictness. The phenomenon of hijrah shows the view that piety should be appeared in outward form. This research illustrates that hijrah is not always a role model of piety, but it can also be a spread of frozen ideology, depicting the commodification of religion, and is considered as discussing only halāl and harām issues. Applying qualitative approach, this study takes the data in litterer source both the religious text and media. The sources of data in media come from media statements related to the hijrah phenomenon. The research results show: first, hijrah is interesting for some Muslims because Islamic teachings are more practical, less philosophical and complicated. Second, the meaning of hijrah as its original meaning is not limited to aspects of existence; rather, the religious spirit is interpreted as a personal spiritual journey that will continue throughout human life. The shifting phenomenon on hijrah much influenced by media and social media wave that blow up the value of practicality, consumerism, and commodification of religion.
\end{abstract}

\begin{abstract}
Hijrah dianggap sebagai perubahan sikap dan pengalaman keagamaan, dari yang longgar menjadi ketat. Fenomena hijrah menunjukkan anggapan bahwa kesalehan harus tampak dalam wujud lahiriah. Penelitian ini menggambarkan bahwa hijrah tidak selalu menjadi panutan kesalehan, tetapi dapat pula menjadi penyebaran paham yang beku, menggambarkan komodifikasi agama, serta dianggap semata membahas masalah halal dan haram. Dengan menggunakan pendekatan kualitatif, penelitian ini menggunakan data literer, baik teks agama maupun media. Sumber data media diambil dari berita yang berkait dengan fenomena hijrah. Hasil penelitian menunjukkan: pertama, hijrah menarik bagi sebagian kaum Muslim karena pandangan bahwa ajaran Islam lebih praktis, tidak terlalu filosofis dan rumit. Kedua, makna hijrah sebagaimana makna asalnya tidak hanya terbatas pada aspek eksistensi saja, melainkan semangat keberagamaan yang dimaknai sebagai perjalanan spiritual personal yang akan terus berlangsung sepanjang hidup manusia. Fenomena pergeseran hijrah banyak dipengaruhi oleh gelombang media dan media sosial yang mem-blow up nilai kepraktisan, konsumerisme dan komodifikasi agama.
\end{abstract}

Keywords: hijrah; Islam; piety; religious spirit; identity politic

*Corresponding Author: Moh. Ilham A. Hamudy (ilhamhamudy80@gmail.com), Jl. Kramat Raya No. 140 Jakarta Pusat, Daerah Khusus Ibukota Jakarta 10430, Indonesia. 


\section{Introduction}

This study is about the rise of a religious enthusiasm marked by the hijrah movement carried out by most Muslims in Indonesia hijrah in this study. This was the change from a moderate interpretation to Islam's stricter interpretation. Hijrah spread quickly in the Indonesian Moslem's life since it was always in the public eye. We now have the religious spirit combined with an identity politics used to deal with different groups, as hijrah movement and conservative interpretation of Islam cannot be separated. The hijrah movement was marked by the rise of the Quran recitation groups, the use of Muslim clothing, and the increasing Hajj and Umrah pilgrimage members, which was believed to be evidence of a better Moslem (Anonimous 2019). Hijrah movement was seen as the most physical form of piety, as though there was a migration or change toward a more devout Islamic way of life. Although if people referred to the history of hijrah by the Prophet Muhammad PBUH, Hijrah should not only be escapism, running away from the sin of the past life, and repaying them with instant piety (Anonimous 2019).

In Arabic, hijrah means a physical migration from one location to another. This word was popular in the Islamic world because the Prophet Muhammad PBUH migrated from Mecca to Medina (Ismail and Abidin 2017). In the Arab world, this meaning of hijrah stays the same. Only in Indonesia, the meaning of hijrah morphed into a change in religious attitudes: from casual practice to strict practice of religious law (Anonimous 2019).
Hijrah, like other religion-social phenomena, does not just appear suddenly. The hijrah movement appears amid Indonesia's globalization and modernization. This suggests that there is a relationship between hijrah as part of religious rites with the demands of modernity (Putra 2018). Acknowledged or not, the modernization and globalization in Indonesia have a significant impact on the religious community's changing landscape, especially for urban Muslim communities (Ali et al. 2017). The hijrah movement and conservative interpretation of Islam became inseparable. However, this time, conservatism gave birth to new demand: preachers with artistic backgrounds, models that used the trendiest Muslim clothing, and halāl products that needed a promotion from well-known society members.

It drives Muslims' current generation to look for instant moral guidance sources, not in the authoritative Islamic institutions. As a result, their search ends with buying products and spiritual sales that merely reflect religious identity in the form of appearance (Fealy and White 2012:27). For them, religious piety and modernity are equally interesting, and the two are not conflicted. They can have religious piety and popular culture consumption, rather than being forced to choose just one of them. While in the past, people viewed piety and entertainment to conflict with one another. The new generation of Muslims found a way to reconcile those that were traditionally seen as being in opposition. Religion and pop culture now complement each other (Heryanto 2015).

On the other hand, through modernization supported by communication technology, 
Muslim societies increasingly show their hijrah identity by carrying out religious rites in public spaces (Wahid et al. 2019:189). For example, Instagram account Pemuda Hijrah (Hijrah Youth) is followed by more than one million people and the searching for hijrah hashtags resulting in more than 1.7 million posts (Hair 2018). Armed with today's look and clothing, down to earth language, and Muslim cultural attributes, it is easy to label ustadz and ulama on Instagram. An interesting visual, a short video, a caption of motivation to do good, a reproduction of piety, is very easy to find, and it easily attracts many followers (Annisa 2018). The Islamic spirit was also manifested in television programs, Islamic banks, halal tourism, halal certification on each product, and others (Sudiaman 2014). Modernization also has an impact on shifting religious values and orientation, as is the case in the current hijrah phenomenon.

We have seen that the hijrah movement became a massive movement. Hijrah is now considered a happening, festive, and cool, so much so that a hijrah Festival was held. The event was allegedly a success and was attended by many Muslims from various societal levels (Subarkah 2018). This is driven by young urban millennials and driven by artists who also carried out hijrah. Hijrah becomes a new, cool, current lifestyle and has a powerful magnetic force to influence others to join it.

Hijrah for them is not just a spiritual change but also as a lifestyle. Often hijrah is identified with everything that shows a personal religiosity, which is characterized by, for example, changes in fashion, especially for women: those who previously did not wear the hijab then decided to have one, from those who wore a hijab then decided to wear a niqab. For the men: those who have not kept a beard then decide to keep a beard, those who wear the usual long pants and then decide to wear pants that hang over the ankles or wear a robe like an Arab (Setiawan 2017).

So far there were very few studies that carried out on this issue. This study aimed to describe or to provide another point of view, that a hijrah movement may not always mean to be more pious but it might also mean spreading an outdated believe, commodify the religion, and a shallow interpretation of the religion to be a mere "ḅalāl" and "ḅarām" situation. A study by Annisa (2018) focused on the "revival" of Islam in a democratic space that was connected with the growth of social media and internet networks in Indonesia. Micro celebrities were an important component of presenting an Islamic identity in pop culture. According to Annisa, by attracting followers on Instagram, the Muslim microcelebrities can potentially form their own "Islamic public."

A study by Rahman et al. (2018) focused on the discussion on hijrah supported by social media technology, examined how Indonesian Muslim millennials interpret the term hijrah and how they articulate the idea of hijrah as their Islamic identity on social media. The study found that some people feel attracted to hijrah because modern Islamic propaganda through social media is suitable for beginners. It provides information about Islam for free, simple, and easy to understand.

Other studies discussed the history of hijrah. Suarni (2017), stated that hijrah as an un- 
avoidable event for every creature, to give birth to change. Quoting several verses from the Qur'an, Suarni reviews stories of the hijrah of prophets and rasuls before the Prophet Muhammad PBUH. A study by Hakim (2016) discussed the motivation of Prophet Muhammad PBUH to hijrah from Mecca to Medina as God's strategy to enable Islam's message to be more down to earth and felt by humans and other creatures. A study by Ibrohim (2016), interpreted the historical momentum of hijrah of the Prophet Muhammad. That there were individual (spiritual-moral) reforms, socio-cultural reforms, and structural reforms. As such, hijrah was also interpreted as the formation of civil society, pluralist society, and a dynamic ethos.

A study by Lyansari (2019) stated that the Indonesian Muslim community's piety characterized by the hijrah phenomenon among Indonesian celebrities illustrates the economic change to survive after hijrah. Group hijrah by celebrities creates new society trends, which triggered consumerism behavior.

Based on the description above, it seems that the researchers consider hijrah as a phenomenon that arises only from one side. There is no study discussing hijrah comprehensively, starting from the historical perspective of hijrah to its current shift of meaning as part of Indonesia's pop culture. Therefore, this study aimed to fill the hijrah phenomenon gap by discussing it comprehensively from the two sides. First, discussing the historical perspective of hijrah conducted by the Prophet Muhammad PBUH. Second, discussing the current shift of meaning as instant piety by the Indonesian Muslim community.

This study combines descriptive methods and literary analysis of the hijrah phenomenon that attracts Muslim sympathy as a current situation (Sugiyono 2014). The literary analysis was intended to gather the information relevant to the hijrah phenomenon as an instant piety act. This information was obtained by reviewing books, scientific works, thesis, dissertations, encyclopedias, internet, the other sources (Zed 2004).

The approach used in this study was qualitative. This was a suitable approach since the hijrah Movement was considered as multidimensional. The collection of facts and data was done by following the news in mainstream mass media to enrich the analysis. The study was conducted for two months from July 2019 to August 2019.

\section{The Hijrah Phenomenon}

The phenomenon known as hijrah started to touch the Indonesian urban population in the 1980s. Although it did not explicitly use the word "hijrah," the social phenomenon "to become more religious" started to be felt. It could not be separated from the expansion of various transnational Islamism movements originating from other countries, such as Salafi, Wahabi, Jamaah Tabligh, Ikhwanul Muslimin, and Hizbut Tahrir (Rizal 2011). However, it was only later that it became visible since it was suppressed by the New Order regime, which was repressive towards the Islamic movement (Chozin 2013). A similar sentiment was also stated by Arrazy Hasyim, a Lecturer at UIN Jakarta. He stated that the teachings to be more religious, especially Salafis, were able to flourish here because Indonesia after the reform was a freer democratic country compared to Saudi Arabia (bmw/dal 2019). 
Also, a propaganda strategy through social media was used to target young people in this digital age (Wulandari 2019). The millennial communication strategy proved to be effective. Many young people decided to do hijrah: changing their lifestyles, both in faith and appearance. The invitation to join the hijrah movement in social media was even more effective with influencers' involvement, especially if the icon was a celebrity or a public figure (Farabuana and Nurrahmi 2019). The more so if the public figures who become more Islamic or hijrah are young, attractive, and have many fans.

That is why the term "hijrah" was popularized by people who change their behavior and appearance to be more Islamic. Hijrah was made into a trend, a pop lifestyle. In the end, Hijrah became the typical term used by some urban Muslims who tried to change themselves into better, more obedient, and pious individuals. This practice should not be referred to as hijrah. It is more appropriate to be referred to as taubat (repentance) (Anwar 2018). There was a conceptual difference between the current meaning of hijrah in Indonesia and those in the Prophet Muhammad PBUH era from Mecca to Medina (Rohman 2019).

\section{Early History of Hijrah}

The hijrah of Prophet Muhammad PBUH from Mecca to Yathrib (Medina) was a metaphysical event and a historical-sociological event (Munawar-Rachman 2008). It was considered a metaphysical event because Muhammad made a hijrah after he received guidance and permission from Allah. It could be stated that hijrah would not occur without direct intervention from Allah. It was a historical-sociological event since it occurred by following social law. It was a historical event with an immense impact in changing the Islamic world's history (MunawarRachman 2008). It was why Umar bin Khattab chose the event of the Prophet Muhammad PBUH's hijrah as the start of the Islamic Calendar (Pribadi and Haryono 2002).

The Islamic Calendar, Hijriyah, is linked to the hijrah of the Prophet Muhammad PBUH from Mecca to Medina (Putra and Mardiani 2012). Citing Nurcholish Madjid's opinion, Umar's action to choose Muhammad's hijrah as the beginning of the Islamic calendar calculation was in line with this Islamic principle: "Rewards in Jahiliyah time were based on the lineage, and while in Islam it is based on work performance." Therefore, according to Nurcholish, the core meaning of hijrah is the appreciation of work performance. It is in line with one of the Quran's contents, which emphasizes that a person will not obtain anything, except for his efforts (Munawar-Rachman 2008).

From a historical-sociological point of view, the hijrah event was the culmination of a series of events during Muhammad's struggle to establish Islam in Mecca. Muhammad struggled for approximately ten years without satisfactory results. He had many difficulties after the death of his beloved wife, Khadijah, who had been faithfully supporting and accompanying him (Sadiman and Karolina 2017). Then it was followed by the death of Muhammad's uncle, Abu Talib (Munawar-Rachman 2008). These two events made the tenth year a difficult year for the Prophet Muhammad PBUH because the 
Mecca non-believers freely tortured and obstructed His sacred duties (Sasongko 2017).

The strong resistance of the Quraysh tribe of Mecca made him decided to move out of the city, towards the city of Ta'if. The city was chosen since it was not too far away from Mecca, and it was the second most important city in the Hijaz. However, the Ta'if community rejected and resisted the arrival of the Prophet Muhammad PBUH and Zaid ibn Harithah (zal/ape 2009). That rejection forced him to return to Mecca. On the way, the Prophet Muhammad PBUH stopped at the Cave of Hira, his place of retreat, and received the first revelation through the angel Gabriel (Syam 2015). After he had a guarantee of protection from Muthi'im ibn 'Adiy, the strong and kind leader of Naufal clan, Muhammad returned to Mecca and continued his work (Munawar-Rachman 2008).

Upon his arrival at the Kaaba, Mut'im stood upright on his camel and said: "Behold the Quraish! I have given my word to protect Muhammad. Therefore let no one disturb him! " Then, Abu Jahal asked whether Mut'im and his clan had become Muhammad's followers. They replied, "We only gave him protection." Upon hearing this reply, the Bani Makhzum clan could only say: "We will also protect the person you protect." Thus, Muhammad was safe and could return home to continue his work to the tribes around Mecca and Arabia: the tribes or clans of the Bani Maharab, Farazah, Ghassan, Marrah, Hanifah, Suldim, Abs, Kindah, Kalb, Harith, Azrah, Hadzramah, and others. But all that effort passed without a maximum result (Madjid 1995b).

Therefore, the Prophet decided to move from Mecca to Medina (hijrah). The Prophet's hijrah to Medina was not merely moving from one country to another or escaping from the difficulties that befell Mecca's city. However, the hijrah carried out by the Prophet was a strategy in the struggle for the survival of religion and the spread of Islam (to prepare and gather new powers). The Prophet knew the strength of Muslims in Medina, so with this calculation, it was certain that Muslims who emigrated would be free to carry out their worship and teachings of Islam safely. Besides, they can also develop Islamic da'wah freely without getting in the way (Zuraidah 1992:38-41).

Before carrying out the hijrah, the Prophet Muhammad prepared a strategy. Mecca's Muslims did not depart in large groups together, but departed one by one in secret. This strategy was carried out to avoid the attacks of the Quraish who wanted to block them.

The Prophet decided to move from Mecca to Medina (hijrah). The Prophet's hijrah to Medina was not merely moving from one country to another or escaping from the difficulties that befell Mecca's city. However, the hijrah carried out by the Prophet was a strategy in the struggle for the survival of religion and the spread of Islam (to prepare and gather new powers). The Prophet knew the strength of Muslims in Medina, so with this calculation, it was certain that Muslims who emigrated would be free to carry out their worship and teachings of Islam safely. Besides, they can also develop Islamic da'wah freely without getting in the way.

Before carrying out the hijrah, the Prophet Muhammad prepared a strategy. The Mecca's Muslims did not depart in large groups together, but departed one by one in secret. This strategy was carried out in order to avoid the attacks of the Quraish who wanted to block them. 
According to Nurcholish, Muhammad's success in carrying out the hijrah, apart from Allah's miraculous protection, was due to his prowess in strategizing (Madjid 1995b). First of all, Muhammad showed extraordinary leadership by ordering his followers to carry out hijrah to save them. Then he and his two best companions followed them. After arriving at Yathrib, Muhammad began to lay the community's foundations he wanted to build by following Islamic teachings. The community's spirit and style were reflected in Muhammad's decision to change Yathrib's name to Medina, or "the city of par excellence," a place of madaniyah or tamaddun, the civilization (MunawarRachman 2008).

This is the original meaning of hijrah. Hijrah as a historical event is the beginning of the emergence of Islam in the form of religion with a social ethos that creates an egalitarian and democratic society. This is the original meaning of hijrah. As a historical event, hijrah was the emergence of Islam in a religion with a social ethos that created an egalitarian and democratic society. After the hijrah, the Prophet Muhammad PBUH took spectacular steps in shaping the civilization of humankind, starting from the city of Medina (Aswadi 2014), which would become a model for political societies built by the Muslims. One characteristic of Medina society was its pluralistic society: ethnicity, clan, race, and religion. Islam acts as the protector, unifier, and source of civilization. In this city of Medina, a wave of new civilizations was born (Madjid 1995a).

The word madinah (medina) has the same root as madani, even al-din (religion). Etymologically, the word madani can be the contrary of the word badawi, which means nomad. Nomadic communities whose lives are always on the move usually rely solely on physical strength, against nature's ferocity, or in dealing with their enemies. Thus, the nomadic community never leaves a cultural heritage of civilization. On the contrary urban society lives permanently in one place to maintain the continuity of life, which will give birth to social order: law, ethics, culture, and civilization. That is why civilization in Arabic is called hadarah, which has the same root as the word "present." Because without a permanent residence, a civilization could not be built. In Arabic, the center or city of civilization is called Madinah (Medina) (Pribadi and Haryono 2002).

From the brief descriptions above, The Prophet Muhammad's hijrah did not only involve physical activity - the move from Makkah to Yathrib (Medina). Beyond the physical phenomenon, there was also a metaphysical phenomenon, the sheer determination that does not recognize defeat in the struggle to uphold the truth. In Madjid's view, the spiritual spirit of hijrah is: "Abandoning the falsehood, completely moving to the truth, with a willingness to sacrifice and suffer. Believe that God will bestow the final victory upon the warrior of truth." (Madjid 1995b). As the example set by Muhammad, everything must be calculated: making game-plan, tactics, and strategy. That way, the guarantee to succeed will be greater because there is a balanced of faith and proper scientific guidance (QS. al-Mujādilah [58]:11).

The hijrah also commemorates the change of the name of the city of Yathrib to Medina. The change symbolizes the improvement in their civilization and way of life (Munawar-Rachman 2011). It was only after settling in Medina that Muhammad firmly laid the foundations of civil 
society with all Medina's population elements. They all outlined living conditions in a document known as the Medina Charter. According to Madjid, this document introduced, among other things, the spirit of freedom (especially in religion and economics), as well as social and political responsibility (especially defense of their area) (Munawar-Rachman 2008).

The hijrah of Muhammad to Medina brought significant influence. Islam began to grow with the foundation of civilization laid out by Muhammad (Ali 2017). Building this civilized society was what Muhammad did for ten years in Medina (Rohman and Yulianto 2016). Therefore, the hijrah of the Prophet Muhammad PBUH from Mecca to Medina is indeed to build a civil society (Otta 2010).

\section{Instant Piety}

According to Haidar Bagir, the hijrah phenomenon is not new in Indonesia. It had been felt since the 1980s, although at that time, it was not referred to as hijrah (Mauline 2019). At the time, the rise of religious enthusiasm was seen in the Salman Mosque, located across the campus of the Bandung Institute of Technology (ITB). This phenomenon attracted the attention of other students, who were initially not serious about studying religion. The interest started during an international Islamic movement when the Iranian Islamic Revolution broke out in 1979. Khomeini and Ali Shari'ati were popular, but it did not last long because Indonesian Sunni Muslims did not accept the Shi'ite ideology well. However, the Iranian Revolution ignited Islam's passion in Indonesia (Janti 2018). It prompted Islamic activists to show their Islamic identity.

The current phenomenon seems to be solidified and more apparent compared with those in the 1980s. What we are having now is the religious spirit combined with an identity politics used to deal with different groups, while those in the 1980s was more driven by the religious spirit (Mauline 2019). The identity solidification sometimes very extreme, resulting in phobias against other groups (Aziz 2013).

The phenomenon of changing to be "more pious" has long existed and is known as "born again" amongst Christians (Azra 2019). The bornagain people also usually more extreme. Some Muslims even stated that moderate Muslims as Muslims who are "not käffah." (Syahid 2018). Solidification of identity as a form of the spirit of hijrah should not be causing someone to be exclusive, let alone hate those who are different from them. Especially if this idea supposedly comes from the Quran (Umar 2014:183). But lately, many of those who have carried out the "hijrah" immediately judged those who have not done so as sinners (Permana 2018).

In the present context, according to the research results of Setiawan (2017), in general the transformation related to the current version of hijrah can be seen physically, through superficial changes from style A to style B, from no hijab to wearing one, from clean shave to forcing oneself to grow beard, as well as changes in thought and spirituality. Ibrahim (2016) referred to this phase of change as an "individual transformation phase," which is in the form of spiritual-moral change. The current hijrah phenomenon sometimes only involves superficial changes (Saputra, Pujiati, and Muba 2019).

It can be said that the distinctive change of the meaning of hijrah, especially among young urban Muslims today, is that currently, it emphasizes its existential aspects, not its substantial aspects. For example, Hijrah is 
associated with changes in the way to dress a more Islamic way for women. Islamic dress refers to the way of dressing a Muslim or Muslim woman who covers their aurat (wearing long cloth that covers the entire body). The discourse of hijrah for women cannot be separated from the use of hijab, niqab, and other Muslim clothing. As for men, it is forbidden to use isybal (pants that exceed the ankles) because it is a form of arrogance. Men are also encouraged to grow their beards and shave their mustaches to manifest the Prophet's sunnah (Yunus 2019). They usually also have a blacked spot on their forehead as a sign that they often prostrate for a long time while doing their prayer (Riadi 2017:i). Another telltale is the use of Arabic word terms, such as "ukhti" (to refer to sister), "akhi" (to refer to brother), "ana" (to refer to yourself), "antum" (to refer to you), "na'am and la" (to say yes and no), and a number of other terms that are often spoken as the social language of young people who have done hijrah (Qurtuby 2016). Some are willing to give up their work, to completely embrace hijrah (rzr/dal 2019).

From the above descriptions, we can see that the current term of hijrah in Indonesia refers to individual efforts to discard lifestyles that are considered un-Islamic and switch to "Islamic" codes of behavior and clothing, and perform all rituals, both the mandatory rituals and the recommended rituals (Sari and Mahadian 2018). The piety displayed by those who conduct hijrah is about the construction of Islamic identity by implementing strict Islamic principles that are unique to the style and preferences of a new religion (Teguh 2019). It is manifested through many practices: from erecting mosques and wearing hijabs to attending sermons (Yulikhah 2017).
This piety is practiced in private and promoted as popular culture by celebrities who declared that they conducted hijrah (Hutari 2018). That is because the community likes to discuss celebrities' behavior and lives due to their popularity in the community (Amna 2019). Some of the artists that have declared hijrah were Peggy Melati Sukma, Teuku Wisnu, Irwansyah, SunuMatta Band, Alysaa Soebandono, Dewi Sandra, Arie Untung, Fenita Arie, and Kartika Putri (Yulianto 2019). They publicly announce their decision to do hijrah (Putri 2018a).

If we look back, the role of hijrah fashion among celebrities began to be echoed by Rhoma Irama in the 1970s. He and Soneta Band are determined to bring their music and songs as a tool to convey religious values. Moreover, this determination was further strengthened after all Soneta personnel performed the haj pilgrimage and studied religion with an ustadz. With the motto of the Muslim voice based on amar makruf nahi munkar, Rhoma makes his music a medium for preaching because of the religious call to fortify cultural changes due to the rapid changes in times that affect people's thinking, especially young people who fall into the hole of immorality (Ruslan 2012). Furthermore, the 6070s generation also recognized Bimbo and Nasida Ria as icons of Islamic music. Bimbo brought a song that breathed Islam with religious pop streams. Meanwhile Nasida Ria has a flow of kasidah (Karman 2020).

Then in the 1990s musicians such as Sakti (Salman al-Jugjawy), Derry Sulaiman, Yukie Pas Band, or Reza Noah joined in a group of Islamic movements, namely Jamaah Tabligh (founded by Muhammad Ilyas Kandahlawi, a sheikh from Hindustan). This group da'wah can be described 
through a multi-level marketing system: engaging as many people as possible to follow Allah's path. Khuruj or i'tikäf in mosques during a specific period became the mainstay of this group to understand new members regarding Islamic teachings (Putri 2018b).

The popular figure who influenced the development of the hijrah phenomenon increased rapidly in the 2000s. The artist's role as an influencer is very significant, followed by the spread of da'wah through the media. Several artists who moved to inspire their fans. Social media is also increasingly developing, especially Youtube, making invitations to migrate or religion more easily spread widely.

Some examples of artists such as Dewi Sandra are strong figures who have succeeded in making women confident when deciding to move. Her decision to wear the hijab actually inspired many Muslim women also to wear the hijab. If there were rarely a journalist who wore a hijab, it is now considered cool and fashionable.

In general, there are two models of celebrities' hijrah: those who leave the enter- tainment industry and those who remain in the industry but selectively accept jobs that are believed to be permitted in Islam (As'ad 2018). The husband-and-wife duo, Dude Harlino and Alyssa Soebandono, become more selective in accepting job offers (Mutiara, 2019).

While Teuku Wisnu, Reza (Noah), Sakti (Sheila on 7), Peggy Melati Sukma, Bjah (The Fly), and others choose to leave their celebrity lives (Merdekawan 2018). Previously, earlier generations of artists: the late Gito Rollies and Harry Moekti are the most famous examples of "artist repentance" (Tanjung 2017). Actresses such as Astri Ivo and Eva Arnaz also leave the film industry and concentrate on the dissemination of Islam (Rosidha 2017).

There are some differences between the hijrah of older artists and today's artists, specifically in the interaction with their fans (Mawalia 2018). It is easier for current celebrities to display their religious intentions on social media. They are not refraining themselves to post and update their activities, such as associating with fellow hijrah celebrities and

Table 1. Artists and Islam

\begin{tabular}{|c|c|}
\hline Year & Data \\
\hline $1970 \mathrm{~s}$ & $\begin{array}{l}\text { Dangdut musician Rhoma Irama emerged. His songs were heavily influenced by } \\
\text { Islamic culture. }\end{array}$ \\
\hline $1990 \mathrm{~s}$ & $\begin{array}{l}\text { Jamaah Tabliq enters Indonesia It was getting more popular in the 1990s } \\
\text { through musician Bangun Sugito, the lead singer of The Rollies Band. Later, Sakti } \\
\text { Ari Seno (guitarist of Sheila on } 7 \text { Band), llsyah Ryan Reza (drummer of Noah } \\
\text { Band), dan Yuki Arifin Martawidjaja (vocalist of Pas Band), followed his trail. }\end{array}$ \\
\hline $2000 \mathrm{~s}$ & $\begin{array}{l}\text { More Indonesian celebrities are immersed in their religion, such as Inneke } \\
\text { Koesherawati, Peggy Melati Sukma, and Dewi Sandra. }\end{array}$ \\
\hline $2015 \mathrm{~s}$ & $\begin{array}{l}\text { The term "hijrah" became popular amongst youngsters since the emergence of } \\
\text { the Hijrah Youth movement in Bandung by Ustad Hanan Attaki. }\end{array}$ \\
\hline
\end{tabular}


organize religious gatherings by inviting famous clerics or scholars (Nafi'an 2018). This was also confirmed by Dadi Darmadi, who stated that the concept of hijrah as repentance became popular thanks to the celebrity's presence on social media and added that the celebrities also learned from religious teachers who were familiar with social media. Dadi called it digital spirituality (Titiyoga 2019).

One of the "online ulama" who first introduced the term hijrah is Hanan Attaki, who is also the founder of Pemuda Hijrah (Hijrah Youth), a community in the city of Bandung that is able to invite young people to come to the mosque for their spiritual needs (Giovany and Chatamallah 2018). He now has more than seven million followers through social media accounts, such as Youtube and Instagram (Attaki 2019). The spread of hijrah on social media can be seen as power relations, those who can implement marketing branding, with a set of exciting and efficient communication messages. The meaning of hijrah is reconstructed and becomes interesting because it is connecting the religious discourse and the young people's position in society. Through social media, young people are described as entities that need to be directed and given instructions because they cannot make decisions. The digital revolution and the use of social media to spread this piety cannot be stopped (Titiyoga 2019).

The hijrah of celebrities, the hijrah of millennial youth, the hijrah community's growth, and the emergence of activities with Islamic nuanced are rife lately because their presence becomes a new everyday lifestyle. Now, it is easy to find young millennials who practice their religion in the public space. Many of them are increasingly studying Islam. Muslim millennials also actively use social media to share Islamic content (Fajriani 2019). The content that they share on social media tends to be the same: short lectures of religious teachers who are wellknown on social media. Some Islamic contents are also shared by religious teachers or religious leaders who formally studying Islam. Some public figures who have gone through the searching process also share Islamic content on their social media accounts (Shaidra 2017).

Realizing the attention of the newly hijrah millennials, social media took advantage of this opportunity by making accounts with hijrah nuances to provide guidance and motivation for hijrah and as a means for selling goods (Pamungkas 2018). The accounts began to upload hijrah related products such as the shari'a robe, a set of hijab and veil, socks, and books that support the follower to be faithful to the hijrah. To increase the attractiveness of the products, they are usually endorsed by artists or Instagram celebrities who have conducted the hijrah (Puspanidra and Valdiani 2018).

The idol of today's generation of Muslims is a popular, young Muslim person who dares to carry out hijrah. Appearing religious does not mean having to leave the modern and stylish lifestyle (Wardiani 2019). The consumers' intent to buy or consume "Islamic" products will be the pot of gold for those sellers (Larasati, Hati, and Safira 2018). As such, the view that the hijrah community's clothing style is both fashionable and shar'i become stronger. Based on data from the Organization of the Islamic Conference (OIC), currently, Indonesian Muslim fashion exports are ranked third with a value of US $\$ 7.18$ billion, 
after Bangladesh (US\$ 22 billion) and Turkey (US\$ 14 billion) (Nuraini 2015:17-18).

The hijrah phenomenon is currently only interpreted as religious symbols and is still superficial. Some people feel that they are received hidayyah, and then changing their appearance and words to look more religious. It can no longer be distinguished between religion and culture and between tradition and Shari'a law (al-Asymawi 2003:172). In the end, the current hijrah is moving from the past lifestyle to the current lifestyle (which is believed to be much better and Islamic) and part of social phenomena to strengthen their identity to differentiate themselves from the others. This would not be good for the religion itself.

\section{Conclusion}

The hijrah phenomenon that currently attracts many Muslims seems to be more in the teachings of Islam that are practical, not too philosophical, and not complicated. They are more interested in physical appearance and ritual worship, not spiritualism and social wisdom.

Textual understanding and definite rules form the basis of understanding of those who conducted hijrah. Therefore, they think that all religious issues have been determined in religious texts.

Religion becomes rigid like mathematics; it is no longer flexible. So that what is felt with the current interpretation of hijrah is not migration as a personal spiritual journey in a meaningful way. It just shows the shallowness of religious understanding by those who claim to have done hijrah.

As such, hijrah should be returned to its original meanings. That hijrah is not only limited to physical appearance. Hijrah must be move beyond the physical boundaries because true hijrah is not just about wearing a hijab or not, Hijrah is not a matter of the length of the hijab, the shortened pants, and the length of the beard (Aini 2019). The current phenomenon of hijrah has gone beyond the true meaning of hijrah, blurring the line between the sacred and the profane. The spirit of embracing their religion should be a personal spiritual journey, does not need to be publicized, and trigger a dichotomy between "I have done hijrah" and "they have not done hijrah" (Izad 2019). Because the true spiritual journey will continue throughout the person's life.

Even so, we still appreciate anyone's intention to become more devout Muslims (read: hijrah). However, they cannot just jump from one extreme to another. It is best to learn about Islam slowly, with pure intentions, and guided by qualified teachers in religion. Thus, the undesired effect, such as the solidification identity of "I hijrah" against those who do not hijrah, is no longer exists in society's social relations. Because the true purpose of embracing Islam is to have good virtues for fellow humans, it is not just to change one's appearance and physical actions.]

\section{References}

Aini, Qurratul. 2019. "Perempuan dan Hijrah." Harianjogja.Com, May 29.

Ali, Hasanuddin, Lilik Purwandi, Harry Nugroho, Anastasia W. Ekoputri, and Taufiqul Halim. 2017. The Potraits of Urban Moslem Indonesia: Gairah Religiusitas Masyarakat Kota. Alvara Research Center, Jakarta. 
Ali, Ummu Salamah. 2017. "Peradaban Islam Madinah (Refleksi terhadap Primordialisme Suku Auz dan Khazraj)." Kalimah: Jurnal Studi Agama dan Pemikiran Islam 15(2):191-204. doi: 10.21111/klm.v15i2. 1495.

Amna, Afina. 2019. "Hijrah Artis sebagai Komodifikasi Agama." Jurnal Sosiologi Reflektif 13(2):331-50. doi: 10.14421/jsr. v13i12.1531.

Annisa, Firly. 2018. "Hijrah Milenial: Antara Kesalehan dan Populism." Maarif: Arus Pemikiran Islam dan Sosial 13(1):38-54. doi: 10.47651/mrf.v13i1.11.

Anonimous. 2019. "Setelah Artis Ramai-Ramai Berhijrah." Kolom.Tempo.Co. Retrieved (https://kolom.tempo.co/read/1212759/s etelah-artis-ramai-ramaiberhijrah/full\&view=ok).

Anwar, Khoirul. 2018. "Terkadang Kita Memang Kerap Salah Memahami Hijrah.” Islami.Co. Retrieved (https://islami.co/terkadangkita-memang-kerap-salah-memahamihijrah/)

As'ad, Muhammad. 2018. "Celebrities' Repentance: Announcing Piety in Public." ThejakartapostCom. Retrieved (https:// www.thejakartapost.com/academia/2018 /07/20/celebrities-repentanceannouncing-piety-in-publichtml).

Aswadi, Aswadi. 2014. "Refomulasi Epistemologi Hijrah dalam Dakwah." Islamica: Jurnal Studi Keislaman 5(2):339-53. doi: 10.15642/islamica.2011.5.2.339-353.

Asymawi, Muhammad Sa'id al. 2003. Kritik Atas Jilbab. ed. N. D. Mahmada. Jakarta: Jaringan Islam Liberal.

Attaki, Hanan. 2019. "Founder SHIFT Pemuda Hijrah." Instagram.Com.

Aziz, Munawir. 2013. "Masjid sebagai Media Deradikalisasi di Indonesia." Islamic Review: Jurnal Riset dan Kajian Keislaman
2(2):355-74. doi: 10.35878/islamicreview. v2i2.56.

Azra, Azyumardi. 2019. "Prangka dan Bias: Kebangkitan dan Konservatisme Agama" ed. M. Subarkah. Republika.Co.Id. Retrieved (https://www.republika.co.id/berita/pvj6s f385/prangka-dan-bias-kebangkitan-dankonservatisme-agama).

bmw/dal. 2019. "Geliat Penyebaran Hijrah ala Salafi di Indonesia." CNN Indonesia. Retrieved (https://www.cnnindonesia. com/nasional/20190514213319-20394907/geliat-penyebaran-hijrah-alasalafi-di-indonesia).

Chozin, Muhammad Ali. 2013. "Strategi Dakwah Salafi di Indonesia." Jurnal Dakwah 14(1):1-25. doi: 10.14421/jd.2013.14101.

Fajriani, Suci Wahyu. 2019. "Hijrah Islami Milenial Berdasarkan Paradigma Berorientasi Identitas." Sosioglobal: Jurnal Pemikiran dan Penelitian Sosiologi 3(2):77-88. doi: 10.24198/jsg.v3i2.21643.

Farabuana, Puteri, and Febri Nurrahmi. 2019. "Motivasi dan Perilaku Hijrah Followers Akun Istagram Pemuda Hijrah pada Mahasiswa Universitas Syiah Kuala." Jurnal Ilmiah Mahasiswa FISIP Unsyiah 4(3):1-16.

Fealy, Greg, and Shally White. 2012. Ustadz Seleb, Bisnis Moral \& Fatwa Online. Jakarta: Komunitas Bambu.

Giovany, Kirana Tadiya, and Maman Chatamallah. 2018. "Makna Hijrah bagi Komunitas Pemuda Hijrah (Studi Fenomenologi Komunikasi Makna Hijrah bagi Jamaah di Lingkungan Masjid TSM Bandung)." pp. 369-75 in Prosiding Hubungan Masyarakat. Vol. 4.

Hair, Abdul. 2018. "Fenomena Hijrah di Kalangan Anak Muda." Detik.Com. Retrieved (https://news.detik.com/kolom/d3840983/fenomena-hijrah-di-kalangananak-muda). 
Hakim, Abdul. 2016. "Motivasi Hijrahnya Rasulullah Muhammad SAW dari Makkah ke Madinah." Wahana Inovasi 5(2):428-37.

Heryanto, Ariel. 2015. Identitas dan Kenikmatan; Politik Budaya Layar Indonesia. Jakarta: Kepustakaan Populer Gramedia.

Hutari, Fandy. 2018. "Dari Hijab hingga Hijrah." Historia.Id. Retrieved (https://historia.id/ kultur/articles/dari-hijab-hingga-hijrahD8JEm).

Ibrahim, Ibrahim. 2016. "Bangka Tin, and the Collapse of the State Power." GSTF Journal of Law and Social Sciences (JLSS) 5(1):1-7.

Ibrohim, Busthomi. 2016. "Memaknai Momentum Hijrah." Studia Didaktika: Jurnal Ilmiah Pendidikan 10(2):65-74.

Ismail, Muhammad Taufik, and Zaenal Abidin. 2017. "Kontekstualisasi Hijrah sebagai Titik Tolak Pembaharuan Pendidikan." Suhuf 29(1):50-65.

Izad, Rohmatul. 2019. 'Tren 'Hijrah' yang Diperdebatkan." Detik.Com. Retrieved (https://news.detik.com/kolom/d4604026/tren-hijrah-yangdiperdebatkan).

Janti, Nur. 2018. "Membuka Bab Sejarah Jilbab." Historia.Id. Retrieved (https://historiaid/ kultur/articles/membuka-bab-sejarahjilbab-PKkye).

Karman, Robby. 2020. "Musik Islami: Aliran dan Perkembangannya di Indonesia." IBTimes.ID. Retrieved (https://ibtimes.id/ musik-islami-ragam-aliran-danperkembangannya-di-tanah-air/).

Larasati, Ajeng, Sri Rahayu Hijrah Hati, and Anya Safira. 2018. "Religiusitas dan Pengetahuan terhadap Sikap dan Intensi Konsumen Muslim untuk Membeli Produk Kosmetik Halal." Esensi: Jurnal Bisnis dan Manajemen 8(2):105-14. doi: 10.15408/ess.v8i2.7459.
Lyansari, Kirana Nur. 2019. "Hijrah Celebrity Creating New Religiosities, Branding Economics of Lifestyle in the Age of Muslim Mass Consumption." Analisis: Jurnal Studi Keislaman 18(2):211-32. doi: 10.24042/ ajskv18i2.3066.

Madjid, Nurcholish. 1995a. Islam Agama Kemanusiaan: Membangun Tradisi dan Visi Baru Islam Indonesia. Jakarta: Yayasan Wakaf Paramadina.

Madjid, Nurcholish. 1995b. "Pendekatan Sejarah dalam Memahami Hijrah." Retrieved (http://nurcholishmadjid.org/arsipkarya/read/2-1995b-03-pendekatansejarah-dalam-memahami-hijrah).

Mauline, Mauline. 2019. "Born Again dan Semangat Zaman: Mencermati Fenomena Hijrah [Wawancara dengan Haidar Bagir]." Mizan.Com. Retrieved (https://www. mizan.com/born-again-dan-semangatzaman-mencermati-fenomena-hijrah/).

Mawalia, Khefti al. 2018. "Komodifikasi Hijrah Generasi Milenial.” Swarakampus.Com. Retrieved (https://swarakampus.com/web/2018/1 1/01/komodifikasi-hijrah-generasimilenial/).

Merdekawan, Guntur. 2018. "10 Artis Pria Ini Hijrah dan Tinggalkan Dunia Hiburan." KapanlagiCom. Retrieved (https://www. kapanlagi.com/foto/beritafoto/indonesia/10-artis-pria-ini-hijrahdan-tinggalkan-dunia-hiburan.html).

Munawar-Rachman, Budi. 2008. Ensiklopedia Nur Cholish Madjid. ed. A. Gaus-AF, T. Taufiq, M. Ilham, A. N. Zaman, M. Syu'bi, D. Iswadi, and E. Wijayanto. Indramayu: Yayasan Pesantren Indonesia Al-Zaytun.

Munawar-Rachman, Budi. 2011. Membaca Nurcholish Madjid. Jakarta: Democracy Project-Bukupedia. 
Hijrah Movement in Indonesia ....

Nafi'an, Muhammad Ilman. 2018. "Pengajian Para Artis." Dream.Co.Id. Retrieved (https:// www.dream.co.id/news/pengajian-artis180326o.html).

Nuraini. 2015. "Peluang Ekspor Busana Muslim.” Warta Ekspor, April.

Otta, Yusno Abdullah. 2010. "Madinah dan Pluralisme: Studi atas Kepemimpinan Rasulullah Saw." Jurnal Ilmiah Al-Syir'ah 8(2):479-97. doi: 10.30984/as.v8i2.21.

Pamungkas, Arie Setyaningrum. 2018. "Mediatisasi Dakwah, Moralitas Publik dan Komodifikasi Islam di Era Neoliberalisme." Maarif: Arus Pemikiran Islam dan Sosial 13(1):55-75. doi: 10.47651/mrf.v13i1.12.

Permana, Raden Muhammad Wisnu. 2018. "Seperti Apa Sih, Hijrah dan Islam yang Sesungguhnya?" Kumparan.Com. Retrieved (https://kumparan.com/radenmuhammad-wisnu-permana/seperti-apasih-hijrah-dan-islam-yang-sesungguhnya).

Pribadi, Airlangga, and M. Yudhie R. Haryono. 2002. Post Islam Liberal. Bekasi: Gugus Press.

Puspanidra, Tiara, and Dini Valdiani. 2018. "Komunikator dalam Strategi Endorsement (Studi Strategi Endorsement Produsen Kerudung Voal di Instagram)." Wahana: Media Bahasa, Sastra, dan Budaya Wahana 24(2):1-16.

Putra, Hannan, and Dewi Mardiani. 2012. "Inilah Sekilas Sejarah Penanggalan Hijriyah." Republika.Co.Id. Retrieved (https:// republika.co.id/berita/dunia-islam/ khazanah/12/11/14/mdhhka-inilahsekilas-sejarah-penanggalan-hijriyah).

Putra, Lisa Aditia. 2018. "Salah Kaprah Makna Hijrah." Islami.Co. Retrieved (https:// islami.co/salah-kaprah-makna-hijrah/).

Putri, Restu Diantina. 2018a. "Dari Arie Untung Sampai Cinta Penelope: Cerita Hijrah Para Seleb." Tirto.Id. Retrieved (https:// tirto.id/dari-arie-untung-sampai-cintapenelope-cerita-hijrah-para-seleb-cD1d).

Putri, Restu Diantina. 2018b. "Pengaruh Jamaah Tabligh \& Salafi di Tengah Pilihan Artis Berhijrah." Tirto.Id. Retrieved (https:// tirto.id/pengaruh-jamaah-tabligh-salafi-ditengah-pilihan-artis-berhijrah-cD4a).

Qurtuby, Sumanto Al. 2016. "Euforia Bahasa Arab." Geotimes.Co.Id. Retrieved (https:// geotimes.co.id/kolom/euforia-bahasa$\mathrm{arab} /$ ).

Rahman, Taufiqur, Laila Hifziati, Frizki Yulianti Nurnisya, and Adhianty Nurjanah. 2018. "Hijrah and The Articulation of Islamic Identity of Indonesian Millenials Using the Instagram." Universitas Muhammadiyah Yogyakarta, Yogyakarta.

Riadi, Ahmad. 2017. "Pemaknaan 'Atsar al-Sujud' dalam al-Qur'an." Universitas Islam Negeri Syarif Hidayatullah, Jakarta.

Rizal, Syamsu. 2011. Perkembangan Paham Keagamaan Transnasional di Indonesia. ed. A. S. Mufid. Jakarta: Puslitbang Kehidupan Keagamaan.

Rohman, Dudung Abdul, and Agus Yulianto. 2016. "Menjadi Pemimpin Pengubah Sepanjang Masa." Republika.Co.Id. Retrieved (https://www.republika.co.id/berita/oezh 9p396/menjadi-pemimpin-pengubahsepanjang-masa).

Rohman, Nur. 2019. "Hijrah Rasa Taubat." Islamsantun.Org. Retrieved (https:// islamsantun.org/hijrah-rasa-taubat/).

Rosidha, Eka Laili. 2017. "Dulu Bintang Panas, Eva Arnaz Kini Tampil Syar'i.” Liputan6.Com. Retrieved (https://wwwliputan6.com/showbiz/rea d/2935316/dulu-bintang-panas-evaarnaz-kini-tampil-syari).

Ruslan, Heri. 2012. "Rhoma Irama: Sang Penghulu Mempelai Dangdut dan Dakwah." Republika.Co.Id. Retrieved (https:// 
republika.co.id/berita/m2kji3/rhomairama-sang-penghulu-mempelai- dangdutdan-dakwah).

rzr/dal. 2019. "Rela Berhenti Kerja Usai Dengar Kajian 'Hijrah' Basalamah.” CNN Indonesia. Retrieved (https://www.cnnindonesia.com/nasional /20190515165105-20-395196/relaberhenti-kerja-usai-dengar-kajian-hijrahbasalamah).

Sadiman, Sadiman, and Asri Karolina. 2017. "Pendekatan Saintific Quantum dalam Memahami Perjalanan Isra' Nabi Muhammad SAW (Teori Saintifik Modulasi Quantum Isra')." Fokus: Jurnal Kajian Keislaman dan Kemasyarakatan 2(2):200-225. doi: 10.29240/jf.v2i2.326.

Saputra, Sahran, Pujiati Pujiati, and Simanihuruk Muba. 2019. "Gerakan Hijrah Kaum Muda Muslim di Kota Medan (Studi Kasus Gerakan Komunitas Sahabat Hijrahkuu)." Universitas Sumatera Utara, Medan.

Sari, Annisa Novia, and Adi Bayu Mahadian. 2018. "Perilaku Komunikasi Pelaku Hijrah: Studi Fenomenologi Pelaku Hijrah dalam Shift Gerakan Pemuda Hijrah di Kota Bandung." Linimasa: Jurnal Ilmu Komunikasi 1(1):121.

Sasongko, Agung. 2017. "Hijrah Ke Thaif." Republika.Co.Id. Retrieved (https:// republika.co.id/berita/jurnal-haji/ wijhat/17/02/09/ol3xi9313-hijrah-kethaif).

Setiawan, Erik. 2017. "Makna Hijrah pada Mahasiswa FIKOM Unisba di Komunitas (Followers) Account LINE@DakwahIslam." Mediator: Jurnal Komunikasi 10(1):97-108. doi: 10.29313/mediator.v10i1.2152.

Shaidra, Aisha. 2017. "Topik Ramadan: Geliat Dakwah Media Sosial." Tempo.Co. Retrieved (https://ramadan.tempo.co/read/883477 /topik-ramadan-geliat-dakwah-mediasosial).
Suarni, Suarni. 2017. "Sejarah Hijrah dalam Perspektif al-Quran." Jurnal Ilmiah alMu'ashirah 13(2):144-56. doi: 10.22373/ jim.v13i2.2248.

Subarkah, Muhammad. 2018. "Membeludaknya Hijrah Fest: Milenial Tak Peduli Islam?" Republika.Co.Id. Retrieved (https:// republika.co.id/berita/pi1176385/membe ludaknya-hijrah-fest-milenial-tak-peduliislam).

Sugiyono, Sugiyono. 2014. Metode Penelitian Manajemen. Bandung: Alfabeta.

Syahid. 2018. “Awas! 'Jebakan Batman' Islam Moderat." Voa-Islam.Com. Retrieved (https://www.voa-islam.com/read/worldanalysis/2018/02/01/55823/awasjebakan-batman-islam-moderat/).

Syam, M. Basir. 2015. "Kebijakan dan PrinsipPrinsip Kenegaraan Nabi Muhammad SAW di Madinah (622-632 M): Tinjauan Perspektif Pemikiran Politik Islam." Kritis: Jurnal Sosial Ilmu Politik Universitas Hasanuddin 1(1):157-74.

Tanjung, Agib. 2017. "15 Musisi Tanah Air Hijrah Dalami Islam, 'Musik Haram vs Musik Dakwah."' Brilio.Net. Retrieved (https:// www.brilionet/selebritis/15-musisitanah-air-hijrah-dalami-islam-musikharam-vs-musik-dakwah-1707051.html).

Teguh, Irfan. 2019. “Kegersangan Spiritual: Pemicu 'Hijrah' \& Kesalehan Muslim Urban." Tirto.Id. Retrieved (https://tirto.id/ kegersangan-spiritual-pemicu-hijrahkesalehan-muslim-urban-ed2c).

Titiyoga, Gabriel Wahyu. 2019. "Jalan Baru Para Pesohor." Majalah.Tempo.Co. Retrieved (https://majalah.tempo.co/read/laporanutama/157738/jalan-baru-para-pesohor).

Umar, Nasaruddin. 2014. Deradikalisasi Pemahaman al-Quran \& Hadis. Jakarta: Elex Media Komputindo. 
Wahid, Abdul, Irfan Abubakar, Jajang Jahroni, M. Afthon Lubbi Nuriz, and Rita Pranawati. 2019. Masjid di Era Milenial: Arah Baru Literasi Keagamaan. ed. J. Jahroni and I. Abubakar. Jakarta: CSRC.

Wardiani, Sri Rijati. 2019. "Muslimah'S Clothing Brand, Identity, and Myths in Barthes Semiotic Study." El-Harakah: Jurnal Budaya Islam 21(1):83-103. doi: 10.18860/el. v21i1.6188.

Wulandari, Isvita Septi. 2019. "Identitas Keagamaan: Pemuda Hijrah di Kalangan Anak Muda." p. 735 in Proceeding: Otoritas Keagamaan, Politik dan Budaya Masyarakat Muslim, ed. Tim GF. PPS UIN Sunan Kalijaga Yogyakarta.

Yulianto, Agus. 2019. "Berubah Menjadi Lebih Baik (Fenomena Artis Hijrah)." Islampos. Com. Retrieved (https://wwwislampos. com/berubah-menjadi-lebih-baikfenomena-artis-hijrah-119777/).

Yulikhah, Safitri. 2017. "Jilbab: Antara Kesalehan dan Fenomena Sosial." Jurnal Ilmu Dakwah
36(1):96-117. doi: 10.21580/jid.v36.1. 1627.

Yunus, Andi Hikmawati. 2019. "Hijrah: Pemaknaan dan Alasan Mentransformasikan Diri secara Spiritual di Kalangan Mahasiswa." Emik: Jurnal Ilmiah Ilmu-Ilmu Sosial 2(1):89-104.

zal/ape. 2009. "Laporan dari Arab Saudi: Thaif Kota nan Sejuk dan Ujian Berat Sang Rasul Allah." News.Detik.Com. Retrieved (https:// news.detik.com/berita/d-1262874/thaifkota-nan-sejuk-dan-ujian-berat-sang-rasulallah-).

Zed, Mestika. 2004. Metode Penelitian Kepustakaan. Jakarta: Yayasan Pustaka Obor Indonesia.

Zuraidah, Upik. 1992. "Hijrah Ke Madinah sebagai Strategi Politik Muhammad SAW." Universitas Islam Negeri Sunan Ampel Surabaya. 
This page was intentionally left blank. 